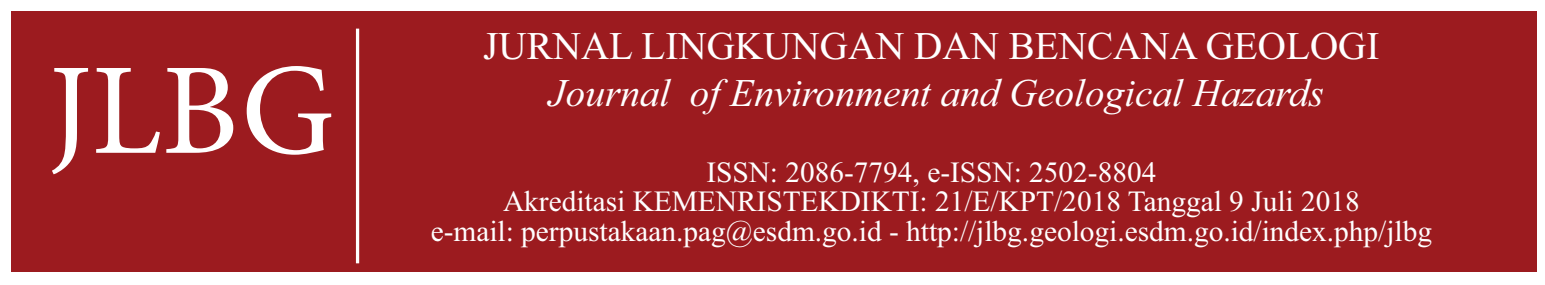

\title{
Analisis Pengaruh Perubahan Lahan terhadap Debit Banjir pada Sub Das Cibeureum, Kawasan Bandung Utara
}

\author{
Analysis of Land Use Change to Flood Discharges \\ in Cibeureum Sub-Watershed, North Bandung Area
}

\author{
Fauziyah Hani, Moh. Sapari Dwi H., dan Hendarmawan \\ Program Studi Magister Teknik Geologi, Fakultas Teknik Geologi, Universitas Padjadjaran \\ Jl. Dipati Ukur No.35, Kota Bandung, Jawa Barat 40132, Indonesia \\ e-mail: fauziyahhani90@gmail.com \\ naskah diterima 6 April 2020, selesai direvisi 20 April 2021, dan disetujui 30 April 2021
}

\begin{abstract}
ABSTRAK
Sub DAS Cibeureum merupakan bagian dari Kawasan Bandung Utara. Pertumbuhan jumlah penduduk mengakibatkan pembangunan terus meningkat dan karena kondisi udaranya sejuk serta pemandangannya indah, Kawasan Bandung Utara menyebabkan lokasi ini banyak diminati. Akibat pemanfaatan lahan untuk pembangunan villa dan kawasan wisata adalah terjadinya perubahan lahan setiap tahunnya. Kawasan Bandung Utara berada di kawasan perbukitan, tersusun oleh batuan vulkanik dan memiliki curah hujan yang cukup tinggi $( \pm 1500-2500 \mathrm{~mm} /$ tahun$)$, sehingga lokasi ini sebagai kawasan resapan air yang baik sehingga memiliki potensi airtanah yang besar. Namun, perubahan lahan yang terus menerus terjadi mengakibatkan kawasan resapan tidak berfungsi dengan baik dan memperbesar debit limpasan permukaan. Akibatnya dapat terjadi krisis sumber daya air dan menyebabkan permasalahan baru salah satunya adalah banjir di hilir sungai. Oleh karena itu, perlu diketahui seberapa besar perubahan tata guna lahan di Sub DAS Cibeureum dan dampaknya terhadap besar debit limpasan di hilir Sub DAS. Dalam penelitian ini penulis menganalisis perubahan lahan dan besar koefisien run-off di Sub DAS Cibeureum pada tahun 2006, 2009, 2011, 2015, 2016, dan 2017. Selanjutnya penulis mengitung besar debit banjir rencana periode ulang 2, 5, 10, 20, 50, dan 100 tahun dengan menggunakan metode rasional. Dari hasil perhitungan didapat bahwa nilai koefisien run-off meningkat setiap tahunnya yang mengakibatkan perhitungan debit banjir rencana berubah dan meningkat. Oleh karena itu, dapat disimpulkan bahwa dalam perencanaan infrastruktur bangunan air atau saluran drainase untuk pengelolaan air perlu dilakukan evaluasi setiap tahunnya dikarenakan tutupan lahan dan nilai koefisien run-off dapat berubah setiap tahunnya.
\end{abstract}

Kata kunci: debit banjir, Kawasan Bandung Utara, koefisien limpasan, perubahan tutupan lahan

\section{ABSTRACT}

Cibeureum sub-watershed is part of the North Bandung area. The growth in population has resulted in development continuing to increase and due to the cool air conditions and beautiful scenery, the North Bandung area has made much in demand. The result land use for the construction of villas and tourist areas is that the land changes every year. The North Bandung area is located in a hilly area, composed of volcanic rocks and has a fairly high rainfall ( $\pm 1500-2500 \mathrm{~mm} /$ year), so this is a good water catchment area meaning has great groundwater potential. However, land changes which continue to occur have resulted in the infiltration area not functioning properly and increasing the discharge of surface run-off. As a result, a water resource crisis can occur and cause new problems, one of which is flooding downstream of the river. Therefore, it is necessary to know the extent of land use change in the Cibeureum Sub-watershed and its impact on the amount of run-off discharge in the downstream of the Subwatershed. In this study we analyzed land changes and the run-off coefficient in the Cibeureum sub-watershed in 2006, 2009, 2011, 2015, 2016 and 2017. Next, we calculated the flood discharge plans for the return period of 2, 5, 10, 20, 50, and 100 years using the rational method. From the results, it was found that the run-off coefficient 
value increases every year and it causes the design flood discharge to changes and increases as well. Therefore, it can be concluded that in planning water infrastructure or drainage channels for water management it is necessary to evaluate every year because the land cover and run-off coefficient values can change every year.

Keywords: flood discharges, North Bandung Area, run-off coefficient, landuse change

\section{PENDAHULUAN}

Sub Daerah Aliran Sungai (DAS) Cibeureum (Gambar 1) merupakan bagian dari kawasan Bandung Utara. Sub DAS Cibeureum menempati sebagian besar Kecamatan Lembang, Kabupaten Bandung Barat. Pada tahun 2014 - 2020, laju pertambahan penduduk Kabupaten Bandung Barat rata-rata meningkat 1,09\% (BPS, 2020). Jumlah penduduk yang meningkat mengakibatkan fenomena urbanisasi terus terjadi di Kawasan Bandung Utara serta mengakibatkan perubahan lahan setiap tahunnya. Faktor pemicu pembangunan perumahan di Bandung Utara selain dipengaruhi oleh faktor fisik lingkungan luas lahan dengan panorama indah dan sejuk juga dipengaruhi oleh faktor aksesibilitas yang baik dan kedekatan dengan tempat kerja (Masri dan Purwaamijaya, 2011)

Curah hujan yang cukup tinggi yaitu sekitar \pm $1500-2500 \mathrm{~mm} /$ tahun (Tabel 5) dan berada di kawasan perbukitan menjadikan Bandung Utara sebagai kawasan resapan air yang baik sehingga memiliki potensi air tanah yang besar. Kawasan ini mempunyai peran yang sangat penting dalam penyediaan air tanah di Cekungan Bandung. Suplai air tanah bagi wilayah cekungan ini sekitar $60 \%$ berasal dari Bandung Utara, dan 40\% sisanya berasal dari Kawasan Bandung Selatan (PERDA JABAR No. 2 Tahun 2016). Di samping itu, perubahan tutupan lahan dari lahan hijau menjadi pemukiman di Bandung Utara, akan mengakibatkan air hujan tidak maksimal meresap ke dalam tanah sehingga, kawasan resapan tidak berfungsi dengan baik (Wibowo, 2011). Hal tersebut dapat menyebabkan krisis sumber daya air dan menyebabkan permasalahan lingkungan. Tercatat antara 2015-2018, wilayah konservasi kritis bertambah di KBU sebesar 1,41\% (Samodro drr., 2020).

Perubahan tutupan lahan memiliki kontribusi pada bertambahnya air limpasan (Nurrochman drr., 2018). Perubahan lahan juga akan berdampak pada suplai air dengan mengubah proses-proses hidrologi seperti infiltrasi, pengisian air tanah, dan limpasan permukaan (Lin et al., 2007). Jika perubahan lahan terjadi di kawasan hulu akan menyebabkan ektremitas debit air yang menimbulkan ancaman banjir dan kekeringan di wilayah hilir DAS (Sabar, 2009). Selain itu, fenomena urbanisasi juga dapat menyebabkan penurunan jumlah dan frekuensi kejadian debit maksimum (Chu drr., 2013).

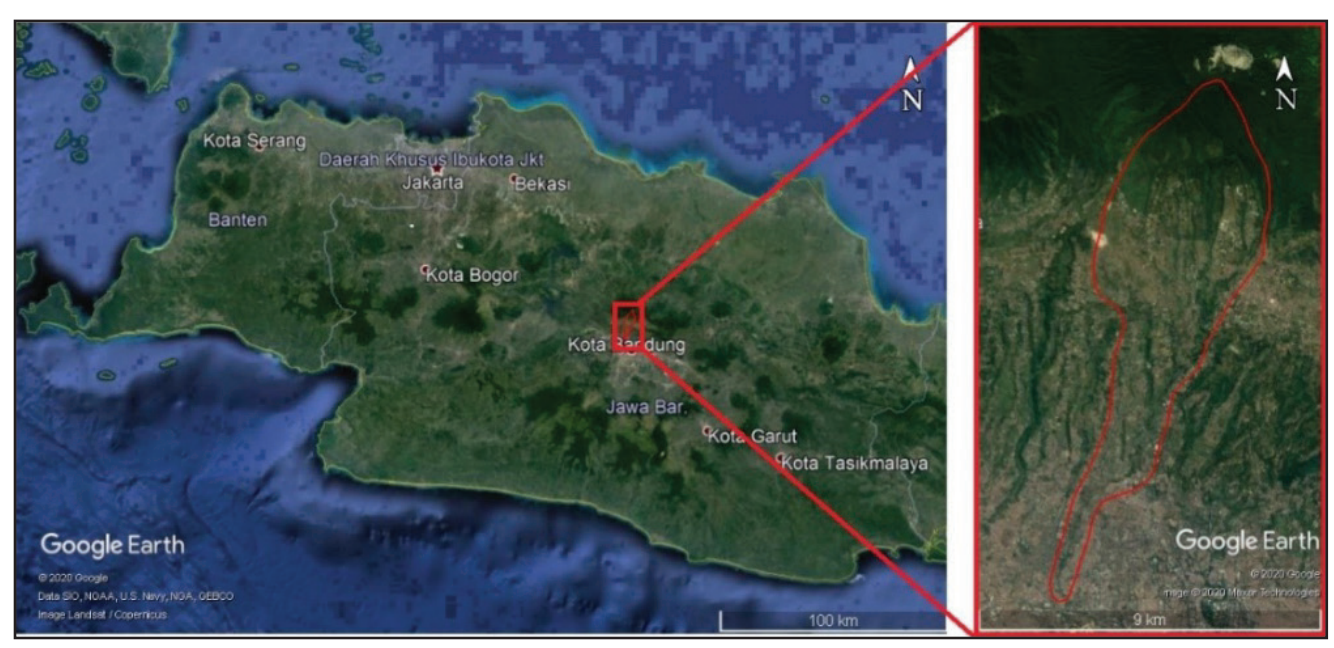

Gambar 1. Lokasi penelitian Sub DAS Cibeureum (http://earth.google.com/web/, diakses januari 2020). 
Selain curah hujan dan tutupan lahan, keadaan topografi mendukung adanya aliran air deras ke bagian lembah di wilayah Bandung bagian tengah dan selatan (Sukiyah drr., 2004). Tercatat pada 2016, daerah Bandung mengalami hujan lebat dengan intensitas hujan $77,7 \mathrm{~mm}$ selama kurang lebih 1,5 jam dan mengakibatkan di daerah Pasteur terjadi banjir (Permana drr., 2018). Contoh lain terjadinya banjir bandang di daerah Cicaheum, Kota Bandung, yang diakibatkan karena ketidakmampuan daerah hulu (Bandung Utara) sebagai kawasan resapan dalam meresapkan air hujan (Nurrohman, 2019)

Daerah Pasteur merupakan bagian hilir dari Sub DAS Cibeureum dan memiliki topografi datar sehingga menjadi potensi area genangan. Oleh karena itu, perlu diketahui seberapa besar perubahan tata guna lahan di Sub DAS Cibeureum dan dampaknya terhadap besar debit limpasan di hilir Sub Das, sehingga dapat dijadikan acuan untuk menentukan strategi konservasi yang tepat dan efektif bagi daerah penelitian agar terhindar dari bencana banjir di kemudian hari.

Berdasarkan Keppres No.12 Tahun 2012, Sub DAS Cibeureum merupakan bagian dari Hulu DAS Citarum dan merupakan bagian dari Wilayah Sungai Citarum. Secara administratif, Sub DAS ini termasuk ke dalam sebagian besar Kecamatan Lembang, Kabupaten Bandung Barat, dan sebagian kecil Kabupaten Bandung serta Kota Bandung. Luas Sub DAS Cibeureum adalah sebesar $31,48 \mathrm{~km}^{2}$.

Berdasarkan Peta Geologi Lembar Bandung (Silitonga, 1973 ) (Gambar 2), batuan yang menyusun Sub DAS Cibeureum didominasi oleh batuan vulkanik. Batuan tersebut di antaranya, Tufa Pasir (Qyd) yaitu tufa pasir coklat sangat berpori, mengandung kristal-kristal hornblenda yang kasar, lahar lapuk kemerah-merahan, lapisan-lapisan lapili dan breksi yang berasal

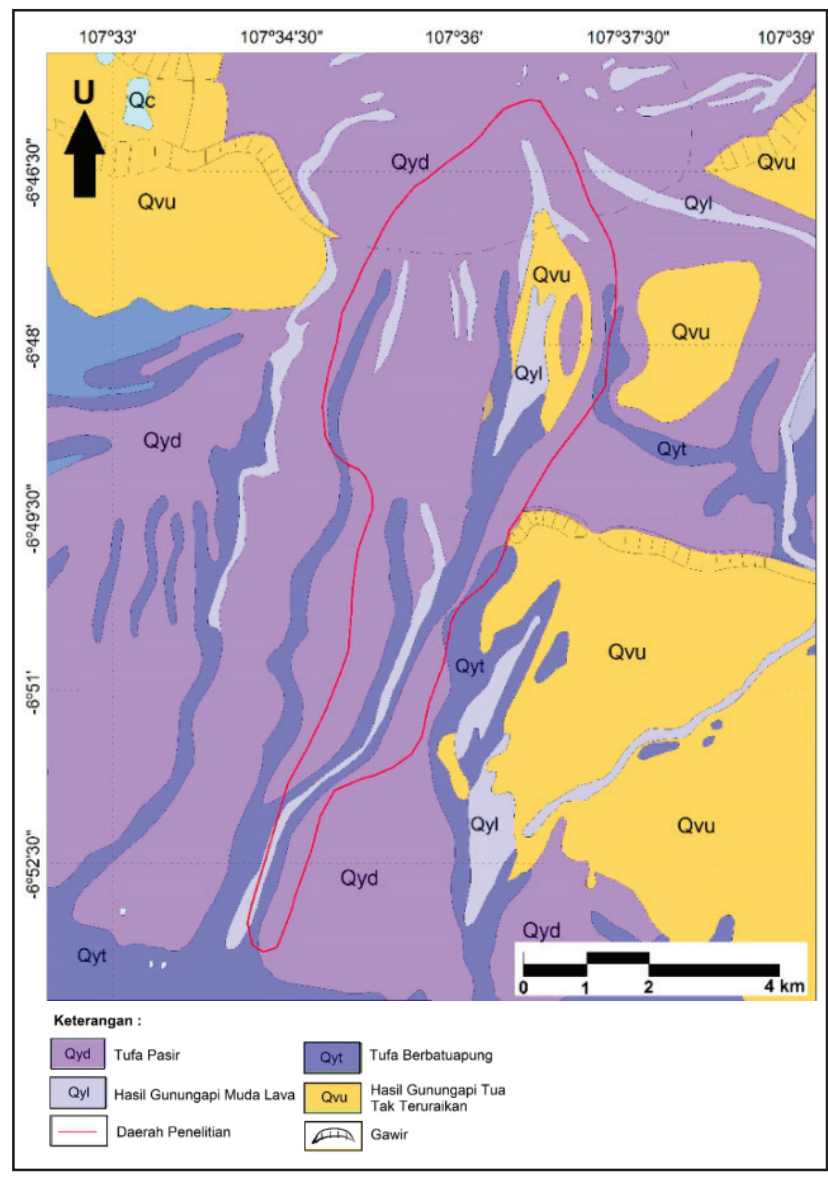

Gambar 2. Peta geologi regional Sub DAS Cibeureum (Modifikasi dari Silitonga, 1973). 
dari G. Dano dan G. Tangkubanparahu (erupsi "C", van Bemmelen, 1934), Hasil Gunungapi Muda Lava (Qyl) yang terdiri atas lava, Tufa Berbatuapung (Qyt) yang terdiri atas pasir tufaan, lapili, bom-bom, lava berongga dan kepingan-kepingan andesit-basal padat yang bersudut dengan banyak bongkah-bongkah dan pecahan-pecahan batuapung berasal berasal dari G.Tangkubanparahu dan G. Tampomas, dan Hasil Gunungapi Tua Tak Teruraikan (Qvu) yang terdiri atas breksi gunungapi, lahar, dan lava berselang-seling.

Berdasarkan Peta Geologi Teknik Lembar Bandung, Jawa Barat (Djadja dan Hermawan, 1996) (Gambar 3), litologi yang menyusun daerah penelitian yaitu terdiri atas Satuan Lanau Lempungan dan Lempung Organik; Satuan Lempung Tufaan dan Lempung Lanauan; Satuan Batupasir, Konglomerat, dan Batupasir Tufaan; dan Satuan Breksi dan Lahar.

\section{METODE PENELITIAN}

Tahap pengolahan data dalam penelitian ini meliputi analisis batas Sub DAS Cibeureum dan analisis karakteristik DAS seperti kemiringan lereng berdasarkan peta topografi dan jenis tanah yang diperoleh peta geologi teknik yang diterbitkan oleh Direktorat Geologi Tata Lingkungan. Selanjutnya inventarisasi data curah hujan dan mengisi data curah hujan yang kosong dengan metode Inversed Square Distance. Kemudian dilakukan pengujian seri data hujan dengan uji konsistensi dan uji homogenitas.Uji Konsistensi data dimaksudkan untuk menguji kebenaran data lapangan yang tidak dipengaruhi oleh kesalahan saat pengiriman atau pengukuran. Data tersebut harus menggambarkan fenomena hidrologi seperti keadaan sebenarnya di lapangan. Cara pengujian konsistensi data hujan dapat dilakukan dengan metode Rescaled Adjusted Partial Sums (RAPS). Dalam metode

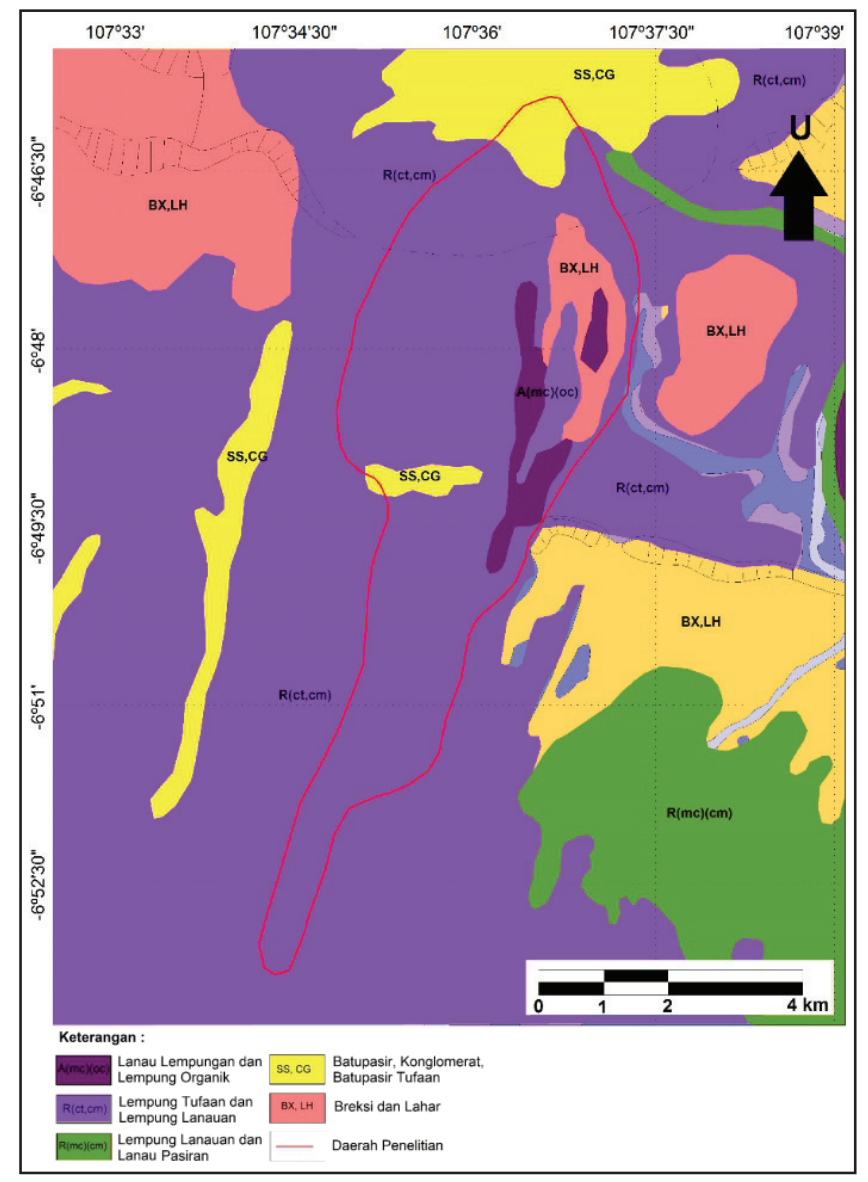

Gambar 3. Peta geologi teknik Sub DAS Cibeureum (Modifikasi dari Djadja dan Hermawan, 1996). 
ini, konsistensi data hujan ditunjukkan dengan nilai kumulatif penyimpangannya terhadap nilai rata-rata berdasarkan persamaan berikut (Kamiana, 2011):

$S k^{*}=\sum_{i=1}^{k}\left(Y_{i}-\bar{Y}\right)$

$\bar{Y}=\frac{\sum Y_{i}}{N}$

dengan $\mathrm{k}=1,2, \ldots \mathrm{N}$; pada saat $\mathrm{k}=0$ maka $\mathrm{Sk}^{*}=0$

$$
\begin{aligned}
& D y^{2}=\sum_{i=1}^{N} \frac{\left(Y_{i}-\bar{Y}\right)}{N} \\
& S k * *=\frac{S k}{D y} \ldots \ldots \ldots \ldots . . .
\end{aligned}
$$

di mana $S k^{*}$ adalah nilai kumulatif penyimpangannya terhadap nilai rata-rata, $Y_{i}$ merupakan nilai data $Y$ ke- $i, \bar{Y}$ adalah nilai $Y$ rata - rata, $n$ adalah jumlah data $Y, \mathrm{Sk}^{* *}$ merupakan nilai Rescaled Adjusted Partial Sums (RAPS), dan $D_{y}$ merupakan deviasi standar seri data $Y$. Setelah Sk** diperoleh untuk setiap $\mathrm{k}$, tentukan nilai Q dan $\mathrm{R}$ terhitung dengan persamaan berikut:

$Q=\left|S k^{* *}\right|$ maks atau $\mathrm{R}=S k^{* *}$ maks $-S k^{* *}$ $\min$

Bandingkan, untuk jumlah data $(n)$ dan derajat kepercayaan $(\alpha)$ tertentu, Jika $\mathrm{Q}_{\text {terhitung }}<\mathrm{Q}_{\text {kritis }}$ atau $\mathrm{R}_{\text {terhitung }}<\mathrm{R}_{\text {kritis }}$, maka seri data yang di analisis adalah konsisten.

Data yang dianggap homogen adalah jika tidak ditemukan adanya perbedaan nilai rata-rata dan varians suatu sub kelompok data dengan sub kelompok data lainnya (Soewarno, 1995). Uji t digunakan untuk melihat homogenitas suatu seri data yang dihitung dengan persamaan:

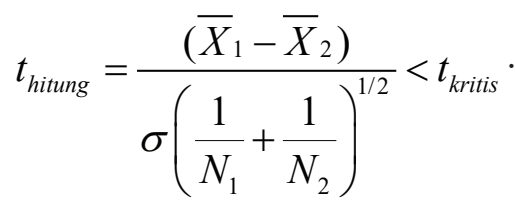

$$
\begin{aligned}
& \sigma=\left(\frac{\left(N_{1} * S_{1}^{2}\right)+\left(N_{2} * S_{2}^{2}\right)}{N_{1}+N_{2}-2}\right)^{1 / 2} \\
& S_{1}=\sum \frac{\left(X_{1 i}-\bar{X}_{1}\right)^{1 / 2}}{N_{1}-1} \\
& S_{2}=\sum \frac{\left(X_{2}-\bar{X}_{2}\right)^{1 / 2}}{N_{1}-1} \\
& D k=N_{1}+N_{2}-2
\end{aligned}
$$

di mana $t$ merupakan variabel - $t$ terhitung, $\underline{X}_{1}$ merupakan rata - rata hitung sampel ke-1, $\bar{X}_{2}$ merupakan rata - rata hitung sampel ke-2, $\mathrm{N}_{1}=$ jumlah sampel set ke- $1, \mathrm{~N}_{2}=$ jumlah sampel set ke-2, $\sigma$ merupakan deviasi standar $S_{1}^{2}$ merupakan varian sampel set ke $-1, S_{2}^{2}$ merupakan varian sampel set ke -2, $d k$ merupakan derajat kebebasan. Berdasarkan hasil perhitungan nilai $\mathrm{t}$ (menggunakan persamaan di atas), akan diperoleh 2 kemungkinan yaitu: $\mathrm{T}$ terhitung $>\mathrm{t}$ kritis; artinya kedua sampel yang diuji tidak berasal dari populasi yang sama, jika $\mathrm{T}$ terhitung $>\mathrm{t}$ kritis; artinya kedua sampel yang diuji berasal dari populas yang sama.

Selanjutnya data yang sudah homogen dan konsisten, dihitung rata-rata curah hujannya menggunakan metode polygon thiessen. Data curah hujan terdiri atas 6 stasiun curah hujan (Cipeusing, Dago Pakar, Kayu Ambon, Lembang, Margahayu, dan Geofisika Bandung). Data tersebut yang diperoleh dari PUSAIR. Metode ini dilakukan dengan cara menghubungkan antara stasiun pencatat hujan terdekat dengan garis putus-putus sehingga membentuk segitiga, lalu dibuat garis berat pada sisi-sisi segitiga dengan garis penuh sehingga membentuk poligon. Persamaan yang dipakai dalam metode ini adalah sebagai berikut (Hadisusanto, 2010):

$$
\bar{p}=\frac{A_{1} p_{1}+A_{2} p_{2}+\ldots+A_{n} p_{n}}{A_{1}+A_{2}+\ldots+A_{n}}
$$

Dimana $\bar{p}$ merupakan jumlah hujan rata-rata kawasan, $\mathrm{p}_{1}, \mathrm{p}_{2}, \ldots, \mathrm{p}_{\mathrm{n}}$, merupakan jumlah hujan 
pada stasiun $1,2, \ldots, n$, dan $A_{1,} A_{2}, \ldots, A_{3}$ merupakan luas daerah mewakil stasiun $1,2, \ldots, n$. Selanjutnya dilakukan analisis hidrologi meliputi analisis data curah hujan rancangan dengan metode distribusi terpilih (Normal, Distribusi Log Normal, Distribusi Gumbel, dan Distribusi Log Pearson Tipe III), perhitungan intensitas curah hujan dengan menggunakan metode Mononobe, dan dilakukan uji distribusi dengan uji Chi Kuadrat dan Smirnov Kolmogorov.

Tahap pertama untuk analisis hidrologi adalah menyiapkan data hujan yang sudah dipilih berdasarkan metode pemilihan data terbaik menurut ketersediaan data. Data curah hujan maksimum diurutkan dari kecil ke besar (atau sebaliknya). Selanjutnya tentukan parameter statistik seperti: mean (X), standard deviation (S), Coefficient of variation (Cv), Coefficient of skewness (Cs), dan Coefficient of kurtosis (Ck). Persamaan untuk menghitung parameter statistk dapat dilihat pada Tabel 1.

Selanjutnya mentukan jenis distribusi yang sesuai berdasarkan parameter statistik yang ada (Distribusi Normal, Distribusi Log Normal, Distribusi Gumbel, Distribusi Log Pearson Tipe III) (Harto, 1993) (Table 2).
Tabel 2. Syarat pemilihan jenis distribusi (Harto, 1993)

\begin{tabular}{lll}
\hline \multicolumn{1}{c}{ Jenis Sebaran } & \multicolumn{2}{c}{ Syarat } \\
\hline Normal & $\mathrm{Cs} \approx 0$ & \\
\hline Log Normal & $\mathrm{Cs} \approx 3 \mathrm{Cv} \quad \quad \mathrm{Cs} \geq 0$ \\
\hline Gumbel & $\mathrm{Cs} \approx 1,4 \quad \quad \mathrm{Ck} \approx 5,4$ \\
\hline Log Pearson III & $\begin{array}{l}\mathrm{Cs}+/- \text {, dan tidak memenuhi } \\
\text { semua syarat diatas }\end{array}$ \\
\hline
\end{tabular}

Persamaan untuk menghitung setiap jenis distribusi ( Soemarto, 1995) dapat dilihat pada Tabel 3. Intensitas curah hujan dihitung dengan menggunakan persamaan Mononobe. Berikut persamaan Mononobe (Hadisusanto, 2010):

$I=\frac{R 24}{224}\left(\frac{24}{T c}\right)^{\frac{2}{3}}$

Di mana $R_{24}$ adalah curah hujan pada periode ulang 2,5,10,20,50,100 tahun dalam satuan $\mathrm{mm} /$ jam dan Tc adalah waktu konsentrasi dalam satuan jam. Untuk menghitung waktu konsentrasi, digunakan persamaan Kirpich (1940):

$$
T c=0,01947 x L^{0,77} x S^{-0,385}
$$

Tabel 1. Persamaan untuk menghitung parameter statistik (Soewarno, 1995)

\begin{tabular}{|c|c|c|}
\hline Parameter & Rumus & Keterangan \\
\hline Nilai Rata-rata & $\bar{X}=\frac{\sum X_{1}}{n}$ & $\begin{array}{l}\bar{X}=\text { nilai rata-rata curah hujan }(\mathrm{mm} / \mathrm{hari}) \\
x_{i}=\text { nilai pengukuran dari suatu curah hujan ke-i }(\mathrm{mm} / \mathrm{hari}) \\
n=\text { jumlah data curah hujan }\end{array}$ \\
\hline Standar Deviasi & $s=\sqrt{\frac{1}{n-1} \sum_{i=1}^{n}\left(X_{i}-\bar{X}\right)^{2}}$ & $\begin{aligned} S & =\text { standar deviasi curah hujan } \\
\bar{X} & =\text { nilai rata-rata curah hujan (mm/hari) } \\
X_{i} & =\text { nilai pengukuran dari suatu curah hujan ke-i (mm/hari) } \\
n & =\text { jumlah data curah hujan }\end{aligned}$ \\
\hline Koefisien Variasi & $C v=\frac{S}{\bar{X}}$ & $\begin{array}{l}C v=\text { Koefisien variasi } \\
S=\text { standar deviasi curah hujan } \\
\bar{X}=\text { nilai rata-rata curah hujan }(\mathrm{mm} / \text { hari })\end{array}$ \\
\hline Koefisien Skewness & $C v=\frac{n \sum_{i=1}^{n}\left(X_{i}-\bar{X}\right)^{3}}{(n-1)(n-2) S^{4}}$ & $\begin{array}{l}C s=\text { Koefisien Skewness } \\
S=\text { standar deviasi curah hujan } \\
\bar{X}=\text { nilai rata-rata curah hujan }(\mathrm{mm} / \mathrm{hari}) \\
x_{i}=\text { nilai pengukuran dari suatu curah hujan ke-i (mm/hari) } \\
n=\text { jumlah data curah hujan }\end{array}$ \\
\hline Koefisien Kurtosis & $C k=\frac{n^{2}}{(n-1)(n-2)(n-3) S^{4}} \sum_{i=1}^{n}\left(X_{i}-\bar{X}\right)^{4}$ & $\begin{array}{l}C k=\text { Koefisien Kurtosis } \\
S=\text { standar deviasi curah hujan } \\
\bar{X}=\text { nilai rata-rata curah hujan (mm/hari) } \\
X_{i}=\text { nilai pengukuran dari suatu curah hujan ke-i }(\mathrm{mm} / \mathrm{hari}) \\
n=\text { jumlah data curah hujan }\end{array}$ \\
\hline
\end{tabular}


Analisis Pengaruh Perubahan Lahan terhadap Debit Banjir pada Sub Das Cibeureum, Kawasan Bandung Utara

Tabel 3. Persamaan setiap jenis distribusi untuk analisis frekuensi curah hujan (Soemarto, 1995)

\begin{tabular}{|c|c|c|}
\hline $\begin{array}{c}\text { Jenis } \\
\text { Distribusi }\end{array}$ & Rumus & Keterangan \\
\hline Normal & $X_{T}=\bar{X}+\left(K_{T} x S\right)$ & $\begin{array}{l}X_{T}=\text { curah hujan rencana }(\mathrm{mm} / \mathrm{hari}) \\
\bar{X}=\text { curah hujan maksimum rata-rata }(\mathrm{mm} / \mathrm{hari}) \\
K_{T}=\text { faktor frekuensi, nilainya tergantung dari T (Variabel Reduksi Gauss) } \\
S=\text { Standar Deviasi }\end{array}$ \\
\hline Log Normal & $\log X_{T}=\log \bar{X}+\left(K_{T} x \operatorname{SLog} X\right)$ & $\begin{array}{l}X_{T}=\text { curah hujan rencana }(\mathrm{mm} / \mathrm{hari}) \\
\bar{X}=\text { curah hujan maksimum rata-rata (mm/hari) } \\
K_{T}=\text { faktor frekuensi, nilainya tergantung dari T (Variabel Reduksi Gauss) } \\
S=\text { Standar Deviasi }\end{array}$ \\
\hline Gumbel & $X_{T}=\bar{X}+(S / S n)(Y-Y n)$ & $\begin{array}{l}X_{T}=\text { curah hujan rencana }(\mathrm{mm} / \mathrm{hari}) \\
\bar{X}=\text { curah hujan maksimum rata-rata }(\mathrm{mm} / \mathrm{hari}) \\
S=\text { Standar Deviasi } \\
S n=\text { reduced standar } \\
Y n=\text { reduced mean } \\
Y t=\text { reduced variate }\end{array}$ \\
\hline $\begin{array}{l}\text { Log Pearson } \\
\text { III }\end{array}$ & $\log X_{T}=\log \bar{X}+\left(K_{T} x \operatorname{SLog} X\right)$ & $\begin{array}{l}X_{T}=\text { curah hujan rencana }(\mathrm{mm} / \mathrm{hari}) \\
\bar{X}=\text { curah hujan maksimum rata-rata }(\mathrm{mm} / \mathrm{hari}) \\
K_{T}=\text { variabel standar, besarnya tergantung koefisien kepencengan }(\mathrm{Cs} \text { atau } \mathrm{G} \text { pada } \\
\text { tabel frekuensi } \mathrm{K}_{\mathrm{T}} \text { untuk Distribusi Log Perason Tipe III } \\
S=\text { Standar Deviasi }\end{array}$ \\
\hline
\end{tabular}

di mana $T c$ adalah waktu konsentrasi dalam satuan menit, $L$ adalah panjang maksimum perjalanan air dalam satuan meter, $S$ adalah kemiringan daerah aliran sungai dimana $S=\Delta H / L$ dan $\Delta H$ merupakan beda tinggi antara titik terjauh pada daerah aliran sungai dan outlet dalam satuan meter .

Selanjutnya analisis perubahan tutupan lahan dan koefisien limpasan di Sub DAS Cibeureum pada tahun 2006, 2009, 2011, 2015, 2016, dan 2017. Data tutupan lahan diperoleh dari Peta Tutupan Lahan Jawa Barat yang di terbitkan oleh Kementerian Kehutanan . Perhitungan ratarata koefisien run-off pada penelitian ini dihitung berdasarkan jenis tutupan lahan, kemiringan lereng dan jenis tanah (Tabel 3 dan Tabel 4). Contoh Nilai Koefisien air limpasan dapat diihat pada Tabel 4 dan 5.

Untuk menentukan besarnya koefisien run off rata-rata wilayah dapat menggunakan persamaan di bawah ini (Suripin, 2004):

$C=\sum_{I=1}^{N} \frac{C_{I} x A_{i}}{A_{i}}$

Di mana $C$ adalah koefisien aliran permukaan rata-rata, $C i$ adalah koefisien aliran permukaan jenis penutupan lahan $i, A$ adalah luas penutup
Tabel 4. Nilai koefisien limpasan, C, (Kombinasi Kodoatie dan Syarief ( (2005), dan Sayoga (1993)

\begin{tabular}{lc}
\hline \multicolumn{1}{c}{ Penutupan Lahan } & Harga C \\
\hline Hutan Lahan Kering Primer & 0,02 \\
\hline Hutan Lahan Kering Sekunder & 0,03 \\
\hline Hutan Mangrove Sekunder & 0,05 \\
\hline Hutan Rawa Sekunder & 0,15 \\
\hline Hutan Tanaman Industri & 0,05 \\
\hline Perkebunan & 0,4 \\
\hline Pemukiman & 0,6 \\
\hline Pertanian Lahan Kering & 0,1 \\
\hline Pertanian Lahan Kering campur Semak & 0,1 \\
\hline Rawa & 0,2 \\
\hline Sawah & 0,15 \\
\hline Belukar & 0,07 \\
\hline Belukar Rawa & 0,2 \\
\hline Tambak & 0,05 \\
\hline Tanah terbuka & 0,2 \\
\hline Perairan & 0,05 \\
\hline
\end{tabular}

lahan dengan jenis penutupan lahan $i$, dan $\mathrm{n}$ adalah jumlah jenis penutupan lahan $i$.

Tahap terakhir yaitu menghitung debit banjir rencana pada tahun 2006, 2009, 2011, 2015, 2016 dan 2017 dengan periode ulang 2 tahun, 5 tahun 10 tahun, 20 tahun, 50 tahun, dan 100 tahun. Untuk menghitung debit banjir maksimum digunakan metode metode rasional. Metode rasional pada umumnya banyak digunakan untuk menghitung debit banjir pada daerah aliran sungai yang tidak terlalu luas dengan batasan 
Tabel 5. Nilai koefisien run-off berdasarkan tutupan lahan, jenis tanah dan kemiringan lereng (Mahmoud, 2015)

\begin{tabular}{|c|c|c|c|c|c|c|c|c|c|c|c|c|c|}
\hline Land use & $\begin{array}{c}\text { Slope } \\
(\%)\end{array}$ & Sand & $\begin{array}{c}\text { Loamy } \\
\text { sand }\end{array}$ & $\begin{array}{l}\text { Sandy } \\
\text { loam }\end{array}$ & Loam & Silt loam & Silt & $\begin{array}{c}\text { Sandy } \\
\text { clay loam }\end{array}$ & $\begin{array}{l}\text { Clay } \\
\text { loam }\end{array}$ & $\begin{array}{l}\text { Silty } \\
\text { clay } \\
\text { loam }\end{array}$ & $\begin{array}{l}\text { Sandy } \\
\text { clay }\end{array}$ & $\begin{array}{l}\text { Silty } \\
\text { Clay }\end{array}$ & Clay \\
\hline \multirow[t]{4}{*}{ Forest } & $<0,5$ & 0,03 & 0,07 & 0,10 & 0,13 & 0,17 & 0,20 & 0,23 & 0,27 & 0,30 & 0,33 & 0,37 & 0,40 \\
\hline & $0,5-5$ & 0,07 & 0,11 & 0,14 & 0,17 & 0,21 & 0,24 & 0,27 & 0,31 & 0,34 & 0,37 & 0,41 & 0,44 \\
\hline & $5-10$ & 0,13 & 0,17 & 0,20 & 0,23 & 0,27 & 0,30 & 0,33 & 0,37 & 0,40 & 0,43 & 0,47 & 0,50 \\
\hline & $>10$ & 0,25 & 0,29 & 0,32 & 0,35 & 0,39 & 0,42 & 0,45 & 0,49 & 0,52 & 0,55 & 0,59 & 0,62 \\
\hline \multirow{3}{*}{ Grass } & $0,5-5$ & 0,17 & 0,21 & 0,24 & 0,27 & 0,39 & 0,34 & 0,37 & 0,41 & 0,44 & 0,47 & 0,51 & 0,54 \\
\hline & $5-10$ & 0,23 & 0,27 & 0,30 & 0,33 & 0,27 & 0,40 & 0,43 & 0,47 & 0,50 & 0,53 & 0,57 & 0,60 \\
\hline & $>10$ & 0,35 & 0,39 & 0,42 & 0,45 & 0,31 & 0,52 & 0,55 & 0,59 & 0,62 & 0,65 & 0,69 & 0,72 \\
\hline \multirow[t]{2}{*}{ Crop } & $<0,5$ & 0,23 & 0,27 & 0,30 & 0,33 & 0,37 & 0,40 & 0,43 & 0,47 & 0,50 & 0,53 & 0,57 & 0,60 \\
\hline & $0,5-5$ & 0,27 & 0,31 & 0,34 & 0,37 & 0,41 & 0,44 & 0,47 & 0,51 & 0,54 & 0,57 & 0,61 & 0,64 \\
\hline \multirow{3}{*}{ Bare Soil } & $0,5-5$ & 0,37 & 0,41 & 0,44 & 0,47 & 0,51 & 0,54 & 0,57 & 0,61 & 0,64 & 0,67 & 0,71 & 0,74 \\
\hline & $5-10$ & 0,43 & 0,47 & 0,50 & 0,53 & 0,57 & 0,60 & 0,63 & 0,67 & 0,70 & 0,73 & 0,77 & 0,80 \\
\hline & $>10$ & 0,55 & 0,59 & 0,62 & 0,65 & 0,69 & 0,72 & 0,75 & 0,79 & 0,82 & 0,85 & 0,89 & 0,92 \\
\hline IMP & & 1,00 & 1,00 & 1,00 & 1,00 & 1,00 & 1,00 & 1,00 & 1,00 & 1,00 & 1,00 & 1,00 & 1,00 \\
\hline
\end{tabular}

hingga luas $50 \mathrm{~km}^{2}$. Adapun rumus umum metode rasional (Hadisusanto, 2010):

$Q=0,2778 x C x I x A$

di mana $\mathrm{Q}$ adalah debit banjir maksimum dalam satuan $\mathrm{m}^{3} /$ detik, $\mathrm{C}$ adalah koefisien aliran permukaan rata-rata, I adalah Intensitas hujan maksimum dalam satuan $\mathrm{mm} / \mathrm{jam}$, dan A adalah luas daerah aliran sungai dalam satuan $\mathrm{km}^{2}$.

\section{HASIL PENELITIAN}

Berdasarkan analisis curah hujan menggunakan metode polygon thiessen yang dapat dilihat pada Gambar 4, terdapat 6 stasiun curah hujan terdekat yang dapat mewakili daerah penelitian, di antaranya Stasiun Cipeusing, Stasiun Dago Pakar, Stasiun Kayu Ambon, Satsiun Lembang, Stasiun Margahayu, dan Stasiun Geofisika Bandung.

Data curah hujan rata-rata (tahun 2004-2017) tertinggi berada pada Stasiun Margahayu yaitu sebesar 2568,81 mm/tahun. Berdasarkan metode polygon thiessen, rata-rata curah hujan di daerah penelitian antara 2004 - 2017 sebesar 1915,68 $\mathrm{mm} /$ tahun. Berdasarkan klasifikasi Mohr, secara umum bulan basah $(>100 \mathrm{~mm})$ terjadi pada bulan Oktober sampai Mei, sedangkan bulan lembab
(60 - $100 \mathrm{~mm})$ terjadi pada bulan Juni, dan bulan kering $(<60 \mathrm{~mm})$ terjadi pada Juli - Agustus. Data rata-rata curah hujan tahunan pada SubDAS Cibeureum dapat dilihat pada Tabel 6 .

Data rata-rata curah hujan maksimum pada SubDAS Cibeureum dapat dilihat pada Tabel 7. Berdasarkan grafik curah hujan maksimum pada Gambar 5, curah hujan maksimum tertinggi terjadi pada November 2011 yaitu sebesar 222,5 mm/bulan pada Stasiun Cipeusing.

Uji konsistensi dihitung menggunakan metode RAPS (Rescaled Adjusted Partial Sums). Berdasarkan hasil uji RAPS yang dapat dilihat pada Tabel 8, data curah hujan maksimum di semua stasiun dinyatakan konsisten.

Sedangkan dari hasil uji homogenitas dengan menggunakan uji $\mathrm{T}$ yang dapat dilihat pada Tabel 9, data curah hujan maksimum dinyatakan homogen.

Berdasarkan hasil perhitungan dari analisis frekuensi yang dapat dilihat pada Tabel 10, diperoleh bahwa distribusi yang cocok untuk perhitungan curah hujan rancangan maksimum di daerah penelitian adalah distribusi Log Pearson III.

Hasil perhitungan curah hujan rancangan di daerah penelitian menggunakan distribusi Log Pearson III dapat dilihat pada Tabel 11. 
Analisis Pengaruh Perubahan Lahan terhadap Debit Banjir pada Sub Das Cibeureum, Kawasan Bandung Utara

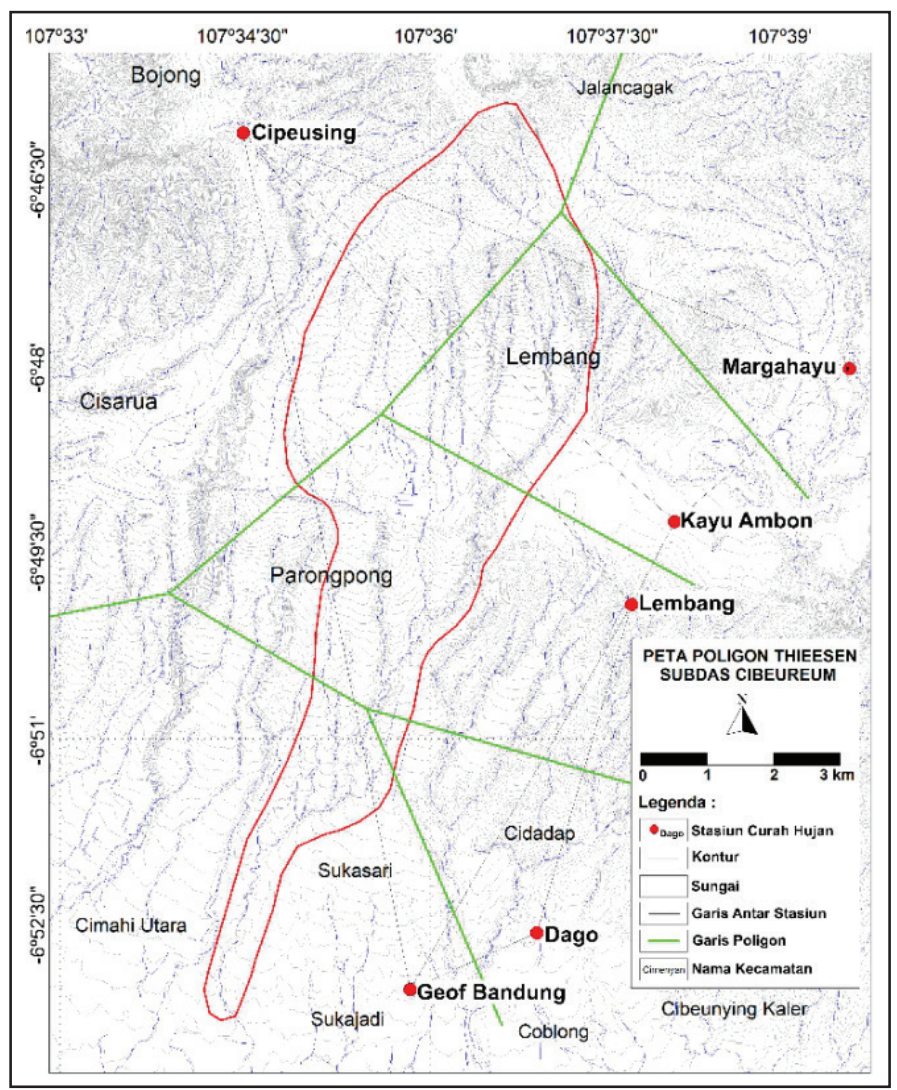

Gambar 4. Peta polygon thiessen SubDAS Cibeureum.

Tabel 6. Rata-rata curah hujan tahunan di Sub DAS Cibeureum

\begin{tabular}{|c|c|c|c|c|c|c|c|}
\hline \multicolumn{7}{|c|}{ 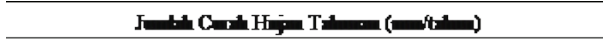 } & \multirow{2}{*}{$\begin{array}{c}\text { RARA } \\
\text { CH } \\
\mathrm{T}\end{array}$} \\
\hline Strix: & Cpescis & $\begin{array}{l}\text { Diso } \\
\text { Pit+e }\end{array}$ & $\begin{array}{l}\text { Krye } \\
\text { Aly bo }\end{array}$ & 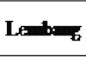 & Malf & 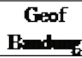 & \\
\hline$x\left(b^{2}\right)$ & 10,43 & 0,26 & 7,15 & 5,811 & 0,03 & 4,725 & 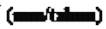 \\
\hline 2004 & 702,0 & 1110,0 & 1200,7 & 1201,0 & 1361,4 & 1929,4 & 1449,9 \\
\hline 2005 & 1662,0 & 1159,0 & 2146,0 & 2319,5 & 92,5 & 232299 & 2053, \\
\hline 2006 & 1156,0 & 1879,0 & 3274,2 & 2127,0 & 3252,4 & 1701,6 & 2001,0 \\
\hline 2007 & 1797,0 & 1932,2 & 2134,3 & 2097,2 & 3019,7 & $217 \pi, 2$ & 2017,8 \\
\hline 2008 & 1400,5 & 1430,0 & 1355,0 & $13411^{3}$ & 35915 & $197 \pi, 4$ & 1462,8 \\
\hline 2009 & 1113,9 & 1690,0 & 1751,0 & 174 & 3 & 2097,6 & 1592,2 \\
\hline 2010 & 2204,5 & 3357,0 & 2561,7 & 2905,4 & 3397,3 & 3693,7 & 2717,6 \\
\hline 2011 & 1839,7 & 1296,0 & 1876,0 & 1959,1 & $202 \pi, 0$ & $17 \pi, 7$ & 187 \\
\hline 2012 & 2074,5 & 1530,0 & 2003,0 & 1269,7 & $22 \%, 1$ & 2510,7 & 2243,4 \\
\hline 2013 & 1181,3 & 2189,0 & 1816,2 & $21 \times 7,9$ & 2475,5 & $26 \pm 0,5$ & 1244, \\
\hline 2014 & 20335 & 1743,0 & 1818,9 & 1632,5 & 2060,2 & $23 \mathbf{4}, 0$ & 1922 \\
\hline 2015 & 2137,0 & 1452,0 & 1713,7 & 769,0 & $1 \sin , 6$ & 2216,1 & 1660 \\
\hline 2016 & 2137,0 & 2167,0 & 1965,8 & 3042,8 & 3016,2 & 3406,2 & 2546 \\
\hline 2017 & 1171,4 & 2303,0 & 1406,9 & 1302,0 & $137 / 5$ & 2024,2 & 1429 \\
\hline mota & 1615,0 & 1902,7 & 2030,5 & $193 \$, 0$ & 2561,8 & $2365 x^{9}$ & 1915 \\
\hline
\end{tabular}

Probabilitas hujan rencana diploting pada grafik log yang dapat digambarkan pada Gambar 6 . Uji distribusi dilakukan dengan uji Smirnov Kolmogorov dan Uji Chi Kuadrat. Dari hasil uji tersebut disimpulkan bahwa distribusi diterima. Hasil uji Smirnov Kolmogorov dapat dilihat pada Tabel 12, sedangkan hasil uji Chi kuadrat dapat dilihat pada Tabel 13 .
Tabel 7. Rata-rata curah hujan maksimum di Sub DAS Cibeureum

\begin{tabular}{|c|c|c|c|c|c|c|c|}
\hline \multicolumn{7}{|c|}{ 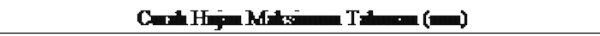 } & \multirow[b]{2}{*}{$\begin{array}{c}\text { RARAm } \\
\text { CHMm }\end{array}$} \\
\hline Sixicie & Cpescis & $\begin{array}{l}\text { Dag } \\
\text { Pilta }\end{array}$ & $\begin{array}{l}\text { Krye } \\
\text { Almbo }\end{array}$ & $L=b=5$ & Maly dye & Geof & \\
\hline $\operatorname{Lag}\left(\mathbf{l}^{2}\right)$ & 10,43 & 0,26 & 7,15 & s,201 & 0,03 & 4,725 & \\
\hline 2004 & 13,00 & $5, \infty$ & $72, \infty$ & $2, \infty$ & 9450 & 70,20 & 55,09 \\
\hline 2005 & 31,00 & 55,00 & 9130 & A. & 56,00 & 5,00 & 69,11 \\
\hline 2006 & $5+\infty$ & $70, \infty$ & 69,00 & 79,50 & $7, \infty$ & 9430 & 72,12 \\
\hline 2007 & 54,00 & 113,00 & 13,50 & 79,00 & 55,00 & 69,50 & 7057 \\
\hline $200 \mathrm{t}$ & 45,00 & $5, \infty$ & 59,10 & 72,00 & $116, \infty 0$ & 67,10 & $60, \mathbf{2}$ \\
\hline 2000 & 37,30 & $73, \infty$ & 5,20 & 7,10 & $145, \infty 0$ & 490 & 67,4 \\
\hline 2010 & 29,00 & $104, \infty 0$ & 70,10 & 69,70 & 76,50 & 122,90 & 6454 \\
\hline 2011 & 222,50 & $45, \infty 0$ & $61, \infty$ & 140,00 & 91,00 & 73,50 & 13159 \\
\hline 2012 & 49,50 & 70,00 & $115, \infty$ & 75,40 & 103,50 & 13,00 & 76,94 \\
\hline 2013 & 30,00 & 95,00 & 95,00 & 9,00 & 7,50 & $6 \pm, 40$ & 69,17 \\
\hline 2014 & 73,00 & 79,00 & 43,50 & 56,00 & 145,50 & 62,00 & 59,97 \\
\hline 2015 & 3,00 & $5, \infty 00$ & 9,00 & 39,00 & 6250 & 7,70 & 73,19 \\
\hline 2016 & 3,00 & 16,00 & 53,00 & 52,23 & 71,50 & 112,60 & 7196 \\
\hline 2017 & $79, \infty$ & $17, \infty$ & 67,46 & 79,50 & 79,50 & 73,50 & $765 t$ \\
\hline Rharh & 63,59 & 7,29 & 75,99 & 7,46 & 94,36 & 2,09 & 73,32 \\
\hline
\end{tabular}

Tabel 8. Hasil Uji RAPS curah hujan maksimum

\begin{tabular}{|c|c|c|c|}
\hline Stro: & Q terlitez & Qkin: & Keteringon \\
\hline Gparsing & 0,95 & 1,14 & Knnsisten \\
\hline Dago Palat & 0,82 & 1,14 & Knnsisten \\
\hline Kayu A-ban & 0,59 & 1,14 & Knnsisten \\
\hline Lembang & 0,99 & 1,14 & Knnsisten \\
\hline Margahayu & 0,73 & 1,14 & Knnsisten \\
\hline Geof Banding & 0,37 & 1,14 & Knnsisten \\
\hline
\end{tabular}


Tabel 9. Hasil uji homogenitas curah hujan maksimum

\begin{tabular}{|c|c|c|c|c|}
\hline \multicolumn{2}{|c|}{ Stan: } & \multirow{2}{*}{ thith } & \multirow{2}{*}{$\begin{array}{c}\text { thilis } \\
\text { 1,706 }\end{array}$} & \multirow{2}{*}{$\begin{array}{l}\text { Keternes } \\
\text { Homogen }\end{array}$} \\
\hline Cpensing & Margaharyu & & & \\
\hline Margahingu & Kayu Ambon & 0,619081144 & 1,706 & Homogen \\
\hline Kayu Aamban & Le=bang & 0,1010072 & 1,706 & Homogen \\
\hline Lembang & Dago Paltar & 0,3750000302 & 1,706 & Hn=ogen \\
\hline Dago Palax & Geaf Banding & 0,209123911 & 1,706 & Honogen \\
\hline
\end{tabular}

Tabel 10. Analisis frekuensi pemilihan distribusi

\begin{tabular}{|c|c|c|}
\hline Jemis Sehare & Syart & HowPerting \\
\hline Nomed & $C s \approx 0$ & \multirow{4}{*}{$\begin{array}{l}\mathrm{Cs}=3,07 \\
\mathrm{C}=0,27 \\
\mathrm{C}=13,57\end{array}$} \\
\hline Log Nomal & $\mathrm{Cs} \approx 3 \mathrm{Cv}$ & \\
\hline G-bed & $C s \approx 1,4$ & \\
\hline Log Pearson III & $\begin{array}{l}\text { Cs+f-, dan tidst memili } \\
\text { semon syart ditas }\end{array}$ & \\
\hline
\end{tabular}

Tabel 11. Hasil perhitungan curah hujan rancangan

\begin{tabular}{|c|c|c|}
\hline $\begin{array}{l}\text { Periode } \\
\text { Ulang }\end{array}$ & $\begin{array}{l}\text { Fahtor } \\
\text { Frehuensi }\end{array}$ & $\begin{array}{c}\text { hyjan Rencana } \\
\text { (m) }\end{array}$ \\
\hline 2 & $-0,351$ & 66,39495615 \\
\hline 5 & 0,537 & 88,213896317 \\
\hline 10 & 1,262 & 93,60326259 \\
\hline 20 & 2,256 & 115,6664132 \\
\hline 50 & 3,023 & 136,1860453 \\
\hline 180 & 3,8 & 160,687/A95 \\
\hline
\end{tabular}

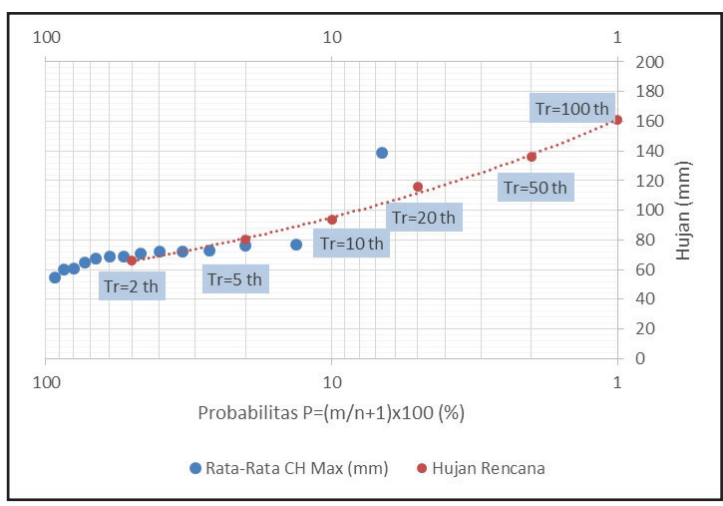

Gambar 6. Plotting probabilitas hujan rencana.

Hasil perhitungan curah hujan rencana dan intensitas curah hujan dengan berbagai durasi dan dengan periode ulang 2, 5, 10, 20, 50, dan 100 tahun dapat dilihat pada Tabel 14.

Berdasarkan grafik pada Gambar 7, semakin lama durasi hujan, intensitas hujan akan semakin
Tabel 12. Perhitungan perbedaan peluang D maks (Uji Distribusi dengan Uji Smirnov Kolmogorov)

\begin{tabular}{|c|c|c|c|c|c|c|}
\hline No & Talle & $\begin{array}{c}\text { Rato Rewa } \\
\text { CHMm } \\
\text { (ए) }\end{array}$ & $\begin{array}{l}\text { Ohatbo bri } \\
\text { terbers } \\
\text { (E) }\end{array}$ & 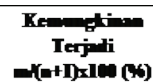 & Teariti (4) & (\%) \\
\hline 1 & 2004 & 55,09 & 138,59 & 6,67 & 1,94 & 4,73 \\
\hline 2 & 2005 & 69,11 & 76,94 & 13,33 & 25,61 & $-12,27$ \\
\hline 3 & 2006 & 72,12 & 76,58 & 20,00 & 26,13 & $-6,13$ \\
\hline 4 & 2007 & 70,57 & 73,19 & 26,67 & 31,86 & $-5,200$ \\
\hline 5 & 2004 & 60,22 & 72,12 & 33,33 & 33,99 & $-0,66$ \\
\hline 6 & 2009 & 67,4 & 71,96 & 40,00 & 34,33 & 5,67 \\
\hline 7 & 2010 & $64,5 t$ & 70,57 & 46,67 & 37,40 & 9,27 \\
\hline I & 2011 & 134,59 & 69,17 & 53,33 & 40,84 & 12,50 \\
\hline 9 & 2012 & 76,94 & 69,11 & 60,00 & 40,99 & 19,01 \\
\hline 10 & 2013 & 69,17 & 67,24 & 66,67 & 44,47 & 22,19 \\
\hline 11 & 2014 & 59,97 & 64,54 & 73,33 & 55,18 & 18,15 \\
\hline 12 & 2015 & 73,19 & 60,22 & 80,00 & 71,79 & 8,21 \\
\hline 13 & 2016 & 71,96 & 59,97 & 86,67 & 76,36 & 10,30 \\
\hline 14 & 2017 & 76,58 & 55,09 & 93,33 & 110,82 & $-17,49$ \\
\hline \multicolumn{3}{|c|}{$\mathrm{D}=\mathrm{tm}=22,19$} & $<$ & Dhitis & 34 & deila \\
\hline
\end{tabular}

Tabel 13. Uji distribusi dengan menggunakan uji chi kuadrat

\begin{tabular}{|c|c|c|c|c|}
\hline Probab-Tas & Ef & of & Ef-Of & $(E F-O)^{2} / E f$ \\
\hline $0<P<20$ & 3 & 1 & 2 & 1,3 \\
\hline $20<P<40$ & 3 & 6 & -3 & $3, \mathbf{0}$ \\
\hline $40<P<68$ & 3 & 4 & -1 & 0,3 \\
\hline $60<P<89$ & 3 & 2 & $\mathbf{1}$ & 0,3 \\
\hline $8 \mathrm{BP}<\mathrm{P}<\mathbf{1 0 B}$ & 2 & 1 & e & $\theta, 0$ \\
\hline Total & 14 & 14 & & 5 \\
\hline \multicolumn{2}{|c|}{ Chi Kuadrat Hitureg : 5} & \multicolumn{3}{|c|}{ Tingkat Kepercayaan : $95 \%$} \\
\hline DK & & Chi Kuac & Kritis & : 7,815 \\
\hline \multicolumn{2}{|c|}{ Derajat signifikasii : $5 \%$} & $x^{2}<x^{2} c$ & $\longrightarrow$ & Diterima \\
\hline
\end{tabular}

kecil dan semakin besar periode ulang, intensitas hujan akan semakin tinggi.

Untuk menghitung intensitas hujan dengan metode Mononobe, terlebih dahulu dihitung nilai waktu konsentrasi menggunakan persamaan Kirpich, dari hasil perhitungan didapat bahwa nilai konsentrasi adalah sebesar 130,30 menit atau 2,17 jam. Karakteristik SubDAS Cibeureum dapat dilihat pada Tabel 15.

Intensitas curah hujan dihitung menggunakan metode Mononobe. Hasil perhitungan intensitas curah hujan dapat dilihat pada Tabel 16.

Berdasarkan peta tutupan lahan pada Gambar 8 , terlihat bahwa terjadi perubahan lahan dari tahun 2006 sampai 2017. Berdasarkan data tutupan lahan tahun 2006, 2009, 2011, 2015, 2016, dan 2017 yang dapat dilihat pada Tabel 17, terjadi perubahan lahan yaitu dari lahan tertutup seperti hutan, pertanian lahan kering, perkebunan menjadi lahan tebuka seperti 
Analisis Pengaruh Perubahan Lahan terhadap Debit Banjir pada Sub Das Cibeureum, Kawasan Bandung Utara

Tabel 14. Periode ulang intensitas hujan daerah kajian dengan berbagai durasi

\begin{tabular}{|c|c|c|c|c|c|c|}
\hline \multirow{3}{*}{$\begin{array}{c}\text { Durasi } \\
\text { [jan] }\end{array}$} & \multicolumn{6}{|c|}{ 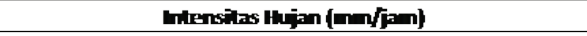 } \\
\hline & $T=2 \mathbf{Y}$ & $\mathbf{T}=\mathbf{5} \mathbf{y}$ & $\mathbf{T}=\mathbf{1 0} \mathbf{Y r}$ & $T=20 \mathrm{y}$ & $T=50 y$ & $\mathrm{~T}=100 \mathrm{yr}$ \\
\hline & 66,39 & 880,21 & 93,60 & 115,67 & 136,19 & 160,69 \\
\hline B,0833 & 139,01 & 155,47 & 17,74 & 184,34 & 291,16 & 213,52 \\
\hline 0,167 & 81,90 & 97,94 & 187,56 & 116,13 & 126,72 & 134,51 \\
\hline 0,25 & 62,50 & 74,74 & 82,108 & 88,62 & 96,71 & 102,65 \\
\hline 0,5 & 39,37 & 47,69 & 51,71 & 55,83 & 60,92 & 64,66 \\
\hline 1 & 24,89 & 29,66 & 32,58 & 35,17 & $\mathbf{3 8 , 3 8}$ & 40,74 \\
\hline 2 & 15,63 & 18,69 & 20,52 & 22,16 & 24,18 & 25,66 \\
\hline 3 & 11,92 & 14,26 & 15,66 & 16,91 & 18,45 & 19,58 \\
\hline 4 & 9,84 & 11,77 & 12,93 & 13,96 & 15,23 & 16,17 \\
\hline 6 & 7,51 & 8,98 & 9,87 & 10,65 & 11,62 & 12,34 \\
\hline 12 & 4,73 & 5,66 & 6,21 & 6,71 & 7,32 & 7,77 \\
\hline 60 & 1,62 & 1,94 & 2,13 & 2,29 & 2,50 & 2,66 \\
\hline
\end{tabular}

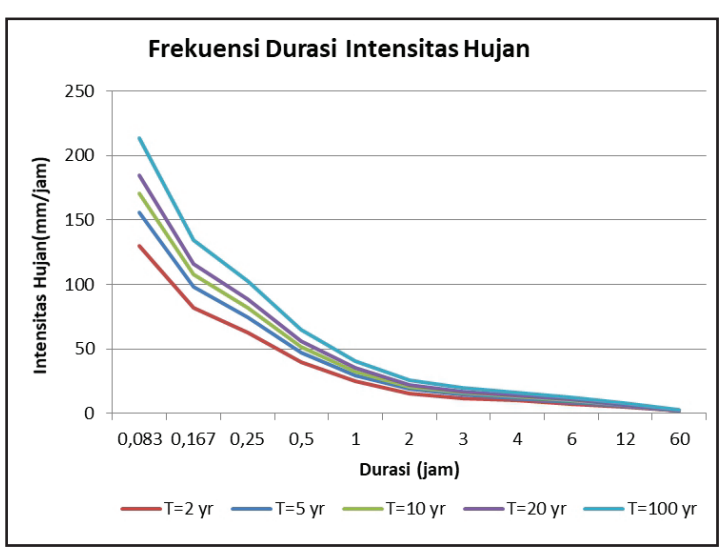

Gambar 7. Grafik frekuensi durasi intensitas hujan.

Tabel 15. Karakteristik SubDAS Cibeureum

\begin{tabular}{|c|c|c|}
\hline Panjarng Sumgai (L) & $18,8 \mathrm{~km}$ & 1898B m \\
\hline Luas SUhDAS Cibeureum (A) & $31,48 \mathrm{~km}^{2}$ & \\
\hline Elevasi Tertinggi & $2050 \mathrm{~m}$ & $2,05 \mathrm{~km}$ \\
\hline Elevasi Tererudah (Outlet) & $762,5 \mathrm{~m}$ & $0,7625 \mathrm{~km}$ \\
\hline $\mathbf{A H}$ & $1287,5 \mathrm{~m}$ & $1,2875 \mathrm{~km}$ \\
\hline S (kemiringan) & 0,0409 & \\
\hline Tc & 130,304 mernit & 2,1717 jam \\
\hline
\end{tabular}

Tabel 16. Intensitas curah hujan di daerah kajian

\begin{tabular}{|c|c|c|c|c|}
\hline $\begin{array}{c}\text { Periode } \\
\text { Utang }\end{array}$ & Probality & $R \max$ & $\begin{array}{c}\text { Ix } \\
\text { [jan) }\end{array}$ & $\begin{array}{c}1 \\
\text { (man) }\end{array}$ \\
\hline 2 & 50 & 66,395 & 2,1717 & 13,725454 \\
\hline 5 & 20 & 80,214 & 2,1717 & 16,580159 \\
\hline 10 & 10 & 93,603 & 2,1717 & 19,350674 \\
\hline 20 & 5 & 115,67 & 2,1717 & 23,911664 \\
\hline 50 & 2 & 136,19 & 2,1717 & 28,152972 \\
\hline 180 & $\mathbf{1}$ & $16 \theta, 69$ & 2,1717 & 33,218962 \\
\hline
\end{tabular}

pemukiman. Luas pemukiman cenderung meningkat setiap tahunnya sehingga mengakibatkan nilai koefisien limpasan pun meningkat.
Nilai koefisien limpasan dihitung berdasarkan jenis tutupan lahan, jenis tanah dan kemiringan lereng. Jenis tanah dan kemiringan lereng cenderung tidak akan berubah, sehingga tutupan lahan merupakan hal yang perlu dikendalikan agar nilai koefisien limpasan tidak terus meningkat setiap tahun. Sebagian besar jenis tanah di daerah kajian adalah lempung lanauan, sehingga laju infiltrasi akan kecil dan limpasan akan semakin besar. Selain itu, kemiringan lereng di bagian hulu relatif terjal. Kemiringan lereng yang terjal akan mengakibatkan aliran air mengalir lebih deras. Hal ini akan mengakibatkan infiltrasi menjadi lebih kecil dan nilai koefisien limpasan semakin tinggi. Oleh karena itu, hal tersebut dapat membuat debit limpasan semakin tinggi. Jika intensitas curah hujan sangat tinggi dan saluran drainase buruk serta tidak dapat menampung debit limpasan maka akan dapat menyebabkan banjir di bagian hilir.

Debit banjir rencana dihitung dengan metode rasional dengan periode ulang 2 tahun, 5 tahun, 10 tahun, 20 tahun, 50 tahun, dan 100 tahun yang dapat dilihat pada Tabel 18. Debit banjir dihitung dengan nilai koefisien limpasan yang berbeda sesuai dengan tutupan lahan pada tahun tertentu.

Berdasarkan hasil perhitungan di atas yang telah digambarkan pada grafik yang terdapat pada Gambar 9, dapat disimpulkan bahwa perubahan lahan akan sangat berpengaruh terhadap besar debit banjir rencana. Karena dengan meningkatnya koefisien limpasan akan mengakibatkan kenaikan dalam perhitungan debit banjir rencana. Perhitungan debit banjir rencana ini biasanya digunakan dalam perencanaan infrastuktur bangunan air seperti drainase, embung, bendungan, dan lain-lain, dimana pembangunan tersebut dimaksudkan untuk pengelolaan air di suatu daerah agar terhindar dari masalah seperti kesulitan mencari air bersih saat kemarau dan bencana banjir ketika musim penghujan.

Berdasarkan penelitian, wilayah Cekungan Bandung memiliki indeks kelembapan topografi yang tinggi, hal ini menununjukan bahwa 


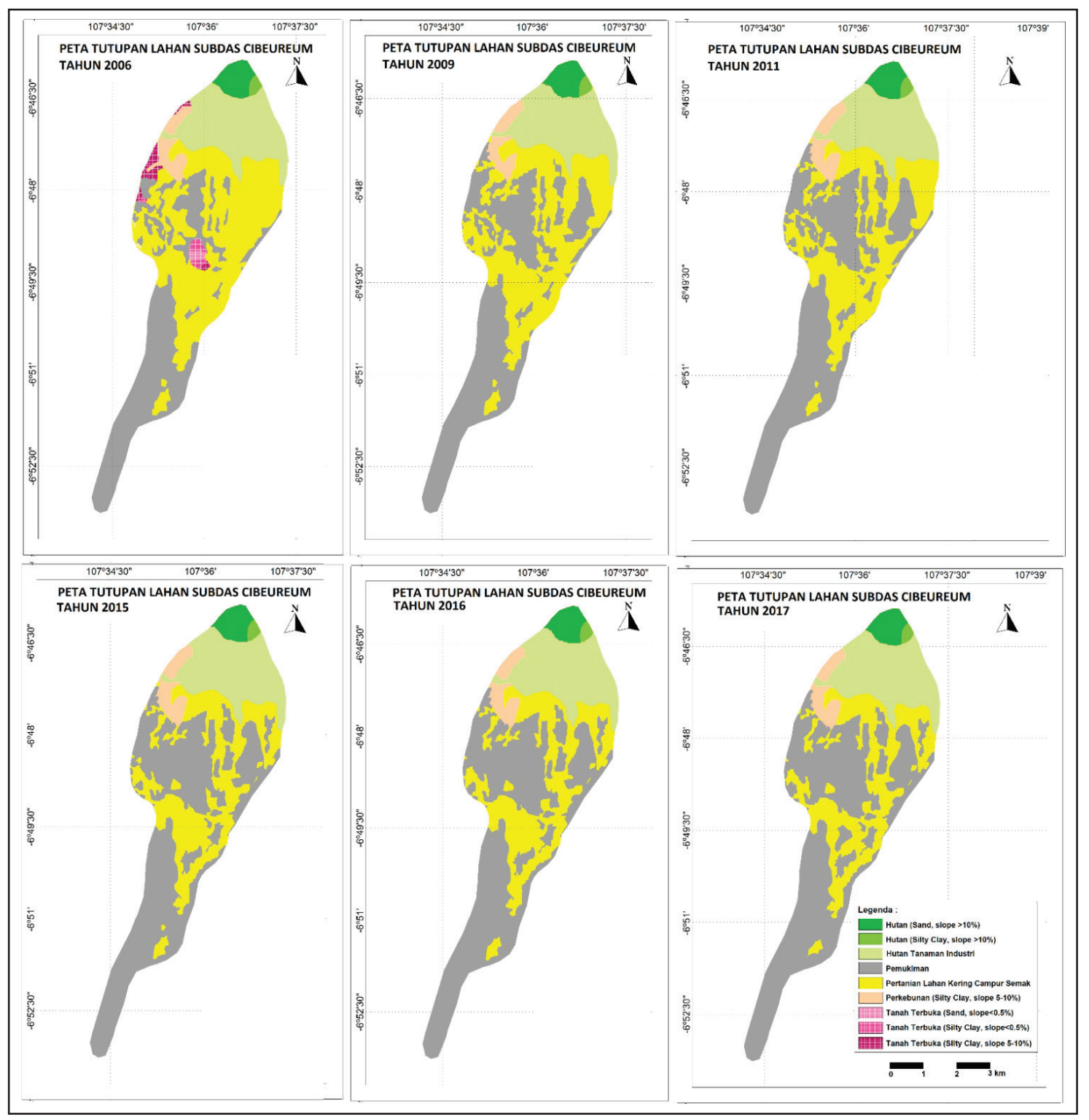

Gambar 8. Peta tutupan lahan SubDAS Cibeureum.

Tabel 17. Data tutupan lahan SubDAS Cibeureum

\begin{tabular}{|c|c|c|c|c|c|c|}
\hline \multirow{2}{*}{ Tutupan Lahan } & \multicolumn{6}{|c|}{$\operatorname{lnas}\left(\ln ^{2}\right)$} \\
\hline & 2006 & 2009 & 2911 & 2015 & 2016 & 2017 \\
\hline Intan (silty clay, >16X) & 0,16 & 0,17 & 0,17 & 0,17 & 0,17 & 0,15 \\
\hline Hutan (sand, >10X) & 0,95 & 0,92 & 0,91 & 0,91 & 0,9 & 0,91 \\
\hline Hutan Tanaman Industri & 5,55 & 5,32 & 5,38 & 5,46 & 5,52 & 5,56 \\
\hline Permukiman & 9,72 & 12,3 & 13,5 & 15,5 & 15,6 & 16 \\
\hline Pertanian Lahan Kering & $\mathbf{0 , 8 8}$ & 1,02 & B,9 & 8,14 & $\mathbf{8 , 0 2}$ & 7,58 \\
\hline Pertanian Lahan Kering Campur Sermak & 12,3 & 10,7 & 9,5 & 0,26 & 0,18 & 0,23 \\
\hline Perkethman (silty day, >10A) & $1, \mathbf{0 3}$ & 0,99 & 1,11 & 1,09 & $1, \mathbf{0 8}$ & $1, \mathbf{0 4}$ \\
\hline Tanah terbuka (silty clay, 0,5-5\%) & 0,26 & - & - & - & - & - \\
\hline Tanah terbuka (silty clay (>104) & $\mathbf{0 , 4 4}$ & - & - & - & - & - \\
\hline Tanah tertndka (sand, 0,5-5\%) & 0,14 & - & - & - & - & - \\
\hline Total & 31,48 & 31,48 & 31,48 & 31,48 & 31,48 & 31,48 \\
\hline Rata Rata Koefisien Rum off & 0,28 & 0,32 & 0,34 & 0,37 & 0,37 & 0,37 \\
\hline
\end{tabular}

wilayah bandung sangat berpotensi terhadap bencana banjir (Irawan, drr., 2018).
Tabel 18. Hasil perhitungan debit banjir rencana

\begin{tabular}{|c|c|c|c|c|c|c|}
\hline \multirow{3}{*}{$\begin{array}{l}\text { Periode } \\
\text { Ulangy }\end{array}$} & \multicolumn{6}{|c|}{ Dehit Banj-Rencana ( ${ }^{3} /$ dettit) } \\
\hline & 2006 & 2009 & 2011 & 2015 & 2016 & 2017 \\
\hline & $\mathrm{c}-0,27 \mathrm{t}$ & $\mathrm{c}=0,316$ & $c-0,337$ & $\mathrm{C}-0,368$ & $\mathrm{C}=0,370$ & $\mathrm{c}=0,375$ \\
\hline 2 & 33,3662 & 37,9271 & 40,4476 & 44,1683 & 44,4053 & 45,0004 \\
\hline 5 & 40,3108 & 45,82009 & 48,266 & 53,3611 & 53,6511 & 54,3761 \\
\hline 10 & 47,0395 & 53,4694 & 57,0222 & 62,2682 & 62,6066 & 63,4526 \\
\hline 20 & $58,12 \pi 2$ & 66,0726 & 70,4635 & 76,9454 & 7,3635 & 78,409 \\
\hline 50 & 68,4392 & $\pi, 7942$ & 22,964 & 90,5957 & $91,0=21$ & 92,319 \\
\hline 100 & 50,7523 & 91,7904 & 97,8904 & 106,895 & 107,476 & 108,922 \\
\hline
\end{tabular}

Oleh karena itu, dengan terus terjadinya perubahan lahan, untuk perencanaan infrastruktur sangat perlu dilakukan perhitungan perencanaan infra- 
Analisis Pengaruh Perubahan Lahan terhadap Debit Banjir pada Sub Das Cibeureum, Kawasan Bandung Utara

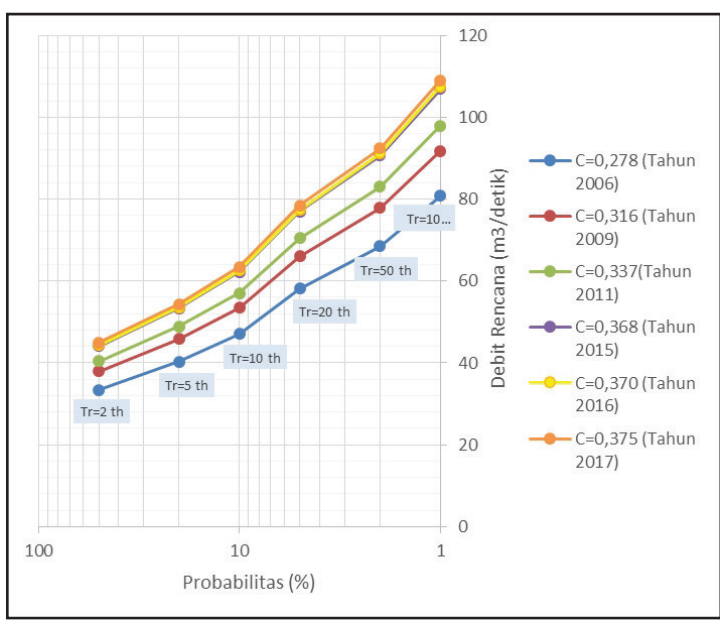

Gambar 9. Garfik debit banjir rencana SubDAS Cibeureum.

struktur yang lebih cermat dan dilakukan evaluasi secara berkala agar terhindar dari kerusakan/ kegagalan infrastuktur. Selain itu, evaluasi tersebut dilakukan untuk melihat apakah bangunan air dapat menampung perubahan debit rencana apa tidak, jika ternyata tidak dapat menampung maka bangunan air perlu dilakukan evaluasi agar dapat menampung debit banjir rencana dan terhindar dari masalah banjir. Selain perubahan lahan, perubahan besar intensitas curah hujan rata-rata yang cenderung berubah juga dapat mempengaruhi besar debit banjir di daerah penelitian. Selain itu, pengaruh antropogenik juga dapat menjadi salah satu faktor yang dapat mengakibatkan sungai tidak dapat menampung debit banjir, di antaranya pengurangan kapasitas tampungan sungai akibat penyumbatan karena tumpukan sampah atau karena menyempitnya lebar sungai akibat pembangunan kota.

Berdasarkan PP No.37 Tahun 2010 evaluasi terhadap infrastruktur sumber daya air, dilakukan minimal lima tahun sekali. Namun, dengan melihat hasil perhitungan perubahan besar debit rencana dari tahun ke tahun di Sub DAS Cibeureum, evaluasi tersebut sepertinya harus dilakukan bahkan maksimal 5 tahun sekali. Hal ini sangat penting, terlebih bagian hilir Sub DAS Cibeureum merupakan daerah Pasteur yang merupakan pintu akses ke Kota Bandung. Topografi yang cenderung datar di daerah Pasteur dapat menjadi daerah genangan saat intensitas hujan tinggi dan debit limpasan melebihi kapasitas tampungan sungai, sehingga jika terjadi banjir, akses transportasi menuju Kota Bandung akan terhambat.

\section{KESIMPULAN}

Perubahan lahan di Kawasan Bandung Utara khususnya Sub DAS Cibeureum terus terjadi setiap tahun, lahan tertutup terus berubah menjadi lahan terbuka, sehingga mengakibatkan luas resapan air menjadi berkurang dan meningkatkan nilai koefisien limpasan. Pada tahun 2006, koefisien limpasan sebesar 0,278 dan pada 2017 meningkat menjadi 0,375, dalam 11 tahun nilai koefisen run-off meningkat sebesar 0,093 (34\%). Hal tersebut mengakibatkan besar debit limpasan meningkat. Tidak heran bila kemarau panjang akan mengalami kesulitan mendapatkan air bersih, dan saat musim penghujan kadang banjir terjadi. Untuk itu diperlukan pengelolaan sumber daya air yang baik agar permasalahan tersebut dapat diatasi. Salah satunya dengan membangun bangunan air seperti drainase yang tepat dan dibangunnya bangunan penampung air seperti embung. Debit banjir rencana dihitung sebagai acuan dalam perencanaan pembangunan infrastruktur sumber daya air. Dari hasil perhitungan, debit banjir rencana di Sub DAS Cibeureum pada setiap tahunnya terus meningkat akibat nilai koefisien limpasan terus meningkat. Oleh karena itu dalam pembangunan infrastruktur sumber daya air di Sub DAS Cibeureum perlu dilakukan evaluasi secara berkala, agar terhindar dari kerusakan/ kegagalan pembangunan infrastruktur.

\section{UCAPAN TERIMA KASIH}

Penulis mengucapkan terima kasih kepada Kepala Laboratorium Geologi Lingkungan dan Hidrogeologi, Fakultas Teknik Geologi Universitas Padjadjaran, Kementerian Kehutanan, dan PUSAIR karena telah memfasilitasi segala keperluan dan memberikan data-data yang dibutuhkan untuk keperluan penelitian ini. 


\section{DAFTAR PUSTAKA}

BPS. 2010. Laju Pertumbuhan Penduduk di Provinsi Jawa Barat Menurut Kabupaten/ Kota, 2014-2020. Diakses pada tanggal 2 Maret 2020 pada situs https://jabar.bps.go.id/ dynamictable/2020/01/30/197/laju-pertumbuhan-penduduk-di-provinsi-jawa-baratmenurut-kabupaten-kota-2014-2020.html

Chu, M.L., Knouft, J.H., Ghulam, A., Guzman, J.A., Pan, Z. 2013. Impacts of Urbanization on River Flow Frequency: A Controlled Experimental Modeling - Based Evaluation Approach. Journal of Hydrology. Elsevier B.V, Vol. 495, 1-12. https://doi.org/10.1016/j. jhydrol.2013.04.051

Djaja dan Hermawan. 1996. Peta Geologi Teknik Lembar Bandung, Jawa Barat. Bandung Direktorat Geologi Tata Lingkungan.

Google Earth. http://earth.google.com/web/ Diakses Januari 2020

Hadisusanto, Nugroho. 2010. Aplikasi Hidrologi. Malang: Jogja Mediautama

Harto, S.B. 1993. Hidrologi : Teori, Masalah, Penyelesaian. Yogyakarta : Nafiri Offset Kamiana, I Made. 2011. Teknik Perhitungan Debit Rencana Bangunan Air. Yogyakarta :Graha Ilmu

Irawan, M. F., Hidayat, Y., dan Tjahjono, B. 2018. Penilaian Bahaya dan Arahan Mitigasi Banjir di Cekungan Bandung.J. II. Tan. Lingk., 20(1) April 2018 :1-6.

http://dx.doi/org/10.29244/jitl.20.1.1-6

Keputusan Presiden Nomor 12 Tahun 2012. Penetapan Wilayah Sungai

Kirpich, T. P. 1940. Time of Concentration of Small Agricultural Watersheds. Civil Engineering, 10(6), 362. https://doi.org/10.1007/ s10333-016-0534-2

Kodoatie, Robert, J. dan Syarief, Roestam. 2005. Pengelolaan Sumber Daya Air Terpadu. Yogyakarta : Andi Offset.

Lin, Y., Hong. N., Wu, P., Wu, C., \& Verburg, P. H. 2007. Impacts of Land Use Change Scenarios on Hydrology and Land Use Patterns in The Wu-Tu Watershed in Northen Taiwan. Landscape and Urban Planning,
80, 111-126. https://doi.org/10.1016/j.landurbplan.2006.06.007

Mahmoud SH, Alazba AA. 2015. Hydrological Response to Land Cover Changes and Human Activities in Arid Regions Using a Geographic Information System and Remote Sensing. PLoS ONE 10(4): e0125805.

https://doi.org/10.1371/journal.pone.012580

Masri, R. M., dan Purwaamijaya, I. M. 2011. Analisis Dampak Lingkungan untuk Pembangunan Perumahan di Kawasan Bandung Utara berbasis Model Sistem Dinamis. Jurnal Permukiman Vol.6 No.3 November $2011: 147-153$.

Nurrochman, drr. 2018. Kajian Sistem Hidrologi Akibat Perubahan Tataguna Lahan Di Kawasan Bandung Utara (Studi Kasus Kabupaten Bandung Barat). Envirosan: Vol.1 Nomor 1, Juni 2018

Nurrohman, Arif. 2019. Pemetaan Kondisi Tutupan Lahan di Sub Daerah Aliran Sungai (DAS) sebagai Tolak Ukur perencanaan Tata Ruang Wilayah. Studi Kasus : Sub DAS Citarum yang ada di Kawasan Bandung Utara. Prosiding Seminar Nasional Geomatika 2018. http://dx.doi.org/10.24895/ SNG.2018.3-0.966

Peraturan Daerah Provinsi Jawa Barat Nomor 2 Tahun 2016 tentang Pengendalian Kawasan Bandung Utara sebagai Kawasan Strategis Provinsi Jawa Barat.

Permana, D.S., Sasmito, A., Kurniawan, R., Sudewi, R.S.S., Hanggoro, W., dan Praja, A.S. 2018. Analisis Hujan Ekstrim Menggunakan Data Satelit Himawari-8 dan Radar Cuaca di Wilayah Bandung Tanggal 24 Oltober 2016. Seminar Nasional Sains dan Antariksa 2017, LAPAN.

Sabar, A. 2009. Perubahan Iklim, Konversi Lahn dan Ancaman Banjir dan Kekeringan di Kawasan Terbangun. Pidato Ilmiah Guru Besar MGB-ITB. Instittut Teknologi Bandung.

Samodro, P., Rahmatunnisa, M., dan Endyana, C. 2020. KAjian Daya Dukung Lingkungan dalam Pemanfaatan Ruang di 
Analisis Pengaruh Perubahan Lahan terhadap Debit Banjir pada Sub Das Cibeureum, Kawasan Bandung Utara

KAwasan Bandung Utara. Jurnal Wilayah dan Lingkungan, 8(3), 214-229. http://doi. org/10.14710/jwl.8.3.214-229

Sayoga, G. R. 1993. Diklat Kuliah Sistem Penyaliran Tambang. Jurusan Teknik Pertambangan ITB, Bandung.

Silitonga, P.H. 1998. Peta Geologi Lembar Bandung, Jawa. Bandung : Pusat Penelitian dan Pengembangan Geologi.

Soemarto, C.D. 1995. Hidrologi Teknik Edisi ke-2. Jakarta:Erlangga.

Soewarno.1995. Aplikasi Metode Statistik Untuk Analaisa Data Hidrologi Jilid I. Bandung: Nova.
Sukiyah, E., Haryanto, A.D., dan Zakaria, Z. 2004. Aplikasi Sitstem Informasi Geografis dalam Penetapan Kawasan Berpotensi Banjir di Kabupaten Bagian Selatan. Bulletin of Scientific Contribution. Volume 2, Nomor 1, Januari 2004: 26-37.

Wibowo, M. 2011. Analisis Pengaruh Perubahan Penggunaan Lahan Terhadap Debit Sungai (Studi Kasus Sub-DAS Cikapundung Gandok, Bandung). Jurnal Teknologi Lingkungan. Vol. 6 No. 1 (2005). https://doi. org/10.29122/jtl.v6i1.328 